\title{
HUBUNGAN INDEKS MASSA TUBUH TERHADAP SKALA SESAK NAPAS PADA PENDERITA PENYAKIT PARU OBSTRUKTIF KRONIK STABIL PRIA
}

\author{
Zulkarnain', AP Tarigan² \\ ${ }^{1}$ program Studi Magister Ilmu Biomedik, Fakultas Kedokteran, UNIVERSITAS \\ SUMATERA UTARA \\ 2Department of Pulmonology and Respirotory Medecine, Faculty of Medecine, \\ UNIVERSITAS SUMATERA UTARA \\ e-mail : zulkarnains.fis@gmail.com
}

DOI : https://doi.org/10.35451/jkf.v2i1.190

\begin{abstract}
COPD is an obstructive pulmonary disease that has a significant impact on the quality of life of patients. Dyspnea, as a major in COPD patients, often occurs when patients do simple things in their daily lives. Several factors contribute to this condition. From several studies, malnutrition as a sign of COPD was often associated with body mass index (BMI). The purpose of this study was to determine whether there is a correlation between BMI and dyspnea scale in COPD patients. This is an analytic study with a cross-sectional design involving 34 male participants with a diagnosis of COPD. BMI was measured by Bioelectrical Impedance Analysis (BIA), and the BORG scale is used to measure the dyspnea scale. The Spearman Tes is used to analyze the correlation between BMI and dyspnea scale. In this study, the majority of patients were obese $(44.1 \%)$, but had a mild difference from the underweight condition $(41.2 \%)$. The BORG median scale is 3.0, with a range of $1-7$. From the analysis, there was no BORG correlation between BMI and dyspnea scale with $p>0.05$. So, it was concluded that there was no significant correlation between BMI and dyspnea scale in COPD patients. Probably due to a few confounding factors that can contribute to this condition.
\end{abstract}

Keywords: Body mass index, dyspnea scale, COPD.

\section{PEndahuluan}

Penyakit paru obstruksi kronik merupakan penyakit golongan obtruktif (Oemiati, 2013). Gejala yang paling sering terjadi pada pasien PPOK adalah sesak napas. Sesak napas menjadi penyebab utama aktivitas fisik menjadi berkurang. Sesak napas biasanya menjadi masalah ketika volume ekspirasi paksa detik pertama $\left(\mathrm{VEP}_{1}\right)$ lebih kecil dari $60 \%$ prediksi (Alfred et al, 2008). Batuk kronis pada PPOK bisa juga muncul dengan atau tanpa adanya dahak, disertai gejala sesak napas yang paling sering terjadi (Vestbo, 2014; Welte, Vogelmeier and Papi, 2015; GOLD, 2017).

Nutrisi akan mempengaruhi kondisi PPOK. Dimana pada penderita PPOK, penurunan fungsi paru berkorelasi dengan malnutrisi (PDPI, 2016). Malnutrisi akan menyebabkan kelainan bentuk, daya regang, faal, 
kemampuan dan pertahanan imunitas paru (Fatisari,2013). Studi yang dilakukan pada 15 penderita PPOK menunjukan adanya hubungan IMT dan $V_{E P}$ yang bermakna dalam keluhan sesak napas yang dirasakan oleh penderita PPOK, Selain itu ditemukan VEP1 yang $<50 \%$ pada penderita PPOK yang memiliki IMT kurang (Sabir \& Kumar, 2016).

Sementara di Indonesia sendiri terutama pada Provinsi Sumatera Utara penelitian mengenai hal tersebut masih terbatas, sehingga peneliti tertarik untuk melihat hubungan dari IMT terhadap skala sesak napas pada penderita penyakit paru obstruktif kronik stabil pria.

\section{METODE}

Penelitian ini merupakan penelitian observasional analitik dengan desain cross sectional. Pengambilan sampel dilakukan dengan metode consecutive sampling pada penderita PPOK di RSU. Siti Hajar Medan. Penelitian ini menggunakan 34 penderita PPOK. Yang dimulai pada Bulan Maret hingga Juli 2019. Kriteria inklusi yang digunakan pada penelitian ini adalah Pria, Umur 40 sampai 80 tahun, mendapatkan perawatan standart (GOLD, 2018) dan kondisi stabil setidaknya 4 minggu sebelum penelitian ini di mulai. Sedangkan kriteria ekslusi antara antara lain Diabetes mellitus, Memiliki penyakit paru lainnya / Tuberkulosis aktif. Data penelitian ini menggunakan data primer dengan cara pengambilan data melalui wawancara dengan kuesioner, dan pemeriksaan spirometri untuk menilai derajat obstruksi. Skala sesak napas diukur dengan skala BORG (Kocks et al., 2013). IMT diukur dengan BIA (Bioelectrical Impedance Analysis) (Knechtle et al., 2011) : Omron model HBF-214 (HBF-214-AP) serial 20161100564F. Untuk menguji hubungan IMT dengan skala sesak napas digunakan uji korelasi spearman.

Adapun penelitian ini telah mendapatkan persetujuan dari Komisi Etik Penelitian Kesehatan Fakultas Kedokteran Universitas Sumatera Utara dengan nomor 128/TGL/KEPK FK USURSUP HAM/2018.

\section{HASIL}

\section{Analisis Univariat}

Uji normalitas data menunjukkan data terdistribusi normal untuk IMT, Berat badan dan tinggi badan dan data tidak terdistribusi normal untuk umur dan skala sesak napas.

Tabel 1: Karakteristik Penderita PPOK Stabil Pria

\begin{tabular}{|c|c|c|c|c|c|}
\hline & Mean & SD & $\mathrm{Me}$ & Min & Maks \\
\hline $\begin{array}{l}\text { Umur } \\
\text { (Tahun) }\end{array}$ & & & 68,50 & 45 & 80 \\
\hline IMT & $\begin{array}{c}24,1 \\
3\end{array}$ & 4,57 & & & \\
\hline $\begin{array}{l}\text { Berat } \\
\text { Badan } \\
(\mathrm{Kg})\end{array}$ & $\begin{array}{c}63,3 \\
5\end{array}$ & $\begin{array}{c}13,0 \\
85\end{array}$ & & & \\
\hline $\begin{array}{l}\text { Tinggi } \\
\text { Badan } \\
(\mathrm{Cm})\end{array}$ & $\begin{array}{c}161 \\
80\end{array}$ & $\begin{array}{c}6,22 \\
4\end{array}$ & & & \\
\hline $\begin{array}{l}\text { Skala } \\
\text { Sesak } \\
\text { Napas }\end{array}$ & & & 3,00 & 1 & 7 \\
\hline
\end{tabular}

\section{Analisis Bivariat}

Tabel 2: Korelasi IMT dengan skala sesak napas.

\begin{tabular}{lrcc}
\hline \multicolumn{2}{c}{ Variabel } & $r$ & $p$ \\
\hline $\begin{array}{l}\text { IMT dengan } \\
\text { Skala sesak }\end{array}$ & $-0,057$ & $0,748^{*}$ \\
napas & & & \\
*Uji spearman $(p>0,05)$ & tidak signifikan.
\end{tabular}

Berdasarkan tabel 2, menjelaskan hubungan IMT dengan skala sesak napas tidak memiliki hubungan, nilai korelasinya menunjukkan hubungan yang negatif dan memiliki hubungan yang lemah. 


\section{PEMBAHASAN}

Berdasarkan hasil yang telah dijelaskan diatas menunjukkan bahwa tidak terdapat hubungan antara IMT dengan skala sesak napas. Hal tersebut berbeda dengan hasil penelitian yang dilakukan oleh (Sabir \& Kumar, 2016) terdapat hubungan IMT dengan skala sesak napas pada penderita PPOK dan penelitian Liu et al. (2015) dan Sabir \& Kumar (2016) yang melaporkan bahwa hubungan IMT dengan skala sesak napas adalah berhubungan, semakin rendah IMT semakin meningkat skala sesak napas penderita.

Penderita PPOK memiliki kecenderungan malnutrisi oleh karena meningkatnya kebutuhan energi akibat dari kerja otot saat proses respirasi yang meningkat, mengakibatkan hipoksemia serta hipermetabolisme, sehingga sering mengalami penurunan berat badan. Kondisi penderita PPOK yang malnutrisi akan semakin menambah mortalitas penderita, penurunan fungsi paru dan perubahan analisis gas darah memiliki hubungan yang signifikan dalam meningkatkan skala sesak napas (Fajrin, 2015).

Sesak napas merupakan kondisi yang tidak menyenangkan saat bernapas (Mularski et al., 2013). Ada beberapa faktor yang menyebabkan tidak terdapat hubungan antara IMT dengan skala sesak napas pada penderita PPOK pada penelitian ini, seperti penggunaan obat-obatan, aktivitas penderita, tingkat obstruksi jalan napas, riwayat merokok dan lama menderita PPOK (PDPI, 2016). Hal terdebut tidak dapat dikendalikan oleh peneliti.

Keterbatasan penelitian ini adalah peneliti tidak mampun untuk mengendalikan faktor-faktor yang dapat mempengaruhi skala sesak napas penderita PPOK stabil. banyak faktor yang berperan terhadap keluhan sesak napas pada penderita PPOK.

\section{KESIMPULAN}

Tidak terdapat hubungan indeks massa tubuh dengan skala sesak napas pada penderita PPOK stabil pria.

\section{DAFTAR PUSTAKA}

Alfred PF, Elias JA, Fishman JA, Grippi MA, Senior RM, Pack AI, editors. (2008). Fishman's Pulmonary Diseases and Disorders. 4th ed. New York: Mc Graw Hill.

Fajrin, O. (2015). Gambaran Status Gizi dan Fungsi Paru Pada Pasien Penyakit Paru Obstruktif Kronik Stabil di Poli Paru RSUD Arifin Achmad. Jom FK Volume 2 No. 2.

Fatisari, M. (2013). Nutrition Therapy in Elderly with Chronic Obstructive Pulmonary Disease (COPD). Sains Medika. Volume 5 No 1. 50-61

GOLD. (2017). 'Global Initiative for Chronic Obstructive Lung A Guide for Health Care Professionals Global Initiative for Chronic Obstructive Disease,' Global initiative for chronic obstructive lung disease.

GOLD. (2018). Global Strategy for Diagnosis, Management, and Prevention of Chronic Obstructive Pulmonary Disease 2017 Report. GOLD Committee. Retrieved from www.goldcopd.org

Knechtle, B., Wirth, A., Knechtle, P., Rosemann, T., Rüst, C. A., \& Bescós, R. (2011). Comparación de la masa grasa y muscular estimada en atletas varones de ultraresistencia utilizando la bioimpedancia eléctrica y diferentes métodos antropométricos. Nutricion Hospitalaria, 26(6), 1420-1427.

Kocks, J. W. H., van den Berg, J. W. K., Kerstjens, H. a M., Uil, S. M., Vonk, J. M., de Jong, Y. P., ... van der Molen, T. (2013). Day-to-day measurement of patient-reported outcomes in exacerbations of chronic obstructive pulmonary disease. International Journal of Chronic Obstructive Pulmonary Disease, 8, 273-286.

Liu, Y., Pleasants, R. A., Croft, J. B., Lugogo, N., Ohar, J., Heidari, K., ... Kraft, M. (2015). Body mass index, 
respiratory conditions, asthma, and chronic obstructive pulmonary disease. Respiratory Medicine, 109(7), 851-859.

Mularski, R. A., Reinke, L. F., CarrieriKohlman, V., Fischer, M. D., Campbell, M. L., Rocker, G., ... White, D. B. (2013). An official american thoracic society workshop report: Assessment and palliative management of dyspnea crisis. Annals of the American Thoracic Society, 10(5).

Oemiati, R. (2013). Kajian Epidemiologis Penyakit Paru Obstruktif Kronik (PPOK). Media Litbangkes, 23(2), 82-88.

PDPI. (2016). PPOK: Diagnosis dan Penatalaksanaan. (M. Amin, Ed.). Jakarta: UI Press.

Sabir, C., \& Kumar, M. S. (2016). Association between Dyspnea , Forced Expiratory Volume in $1 \mathrm{~s}$, and Body Mass Index in Chronic Obstructive Pulmonary Disease, 3(11), 28-31.

Vestbo, J. (2014). COPD: Definition and phenotypes. Clinics in Chest Medicine, 35(1), 1-6.

Welte, T., Vogelmeier, C., \& Papi, A. (2015). COPD: Early diagnosis and treatment to slow disease progression. International Journal of Clinical Practice, 69(3), 336349. 